Note

\title{
Purification and Characterization of $\beta$-Glucosidase Involved in the Emission of 2-Phenylethanol from Rose Flowers
}

\author{
Miwa SaKai, ${ }^{1}$ Saori Tomita, ${ }^{2}$ Hiroshi Hirata, ${ }^{2}$ Tatsuo Asai, ${ }^{2}$ Hideo Dohra, ${ }^{3}$ \\ Masakazu HARA, ${ }^{2}$ and Naoharu WatANABE ${ }^{4, \dagger}$ \\ ${ }^{1}$ The United Graduate School of Agricultural Science, Gifu University (Shizuoka University), \\ 836 Ohya, Suruga-ku, Shizuoka 422-8529, Japan \\ ${ }^{2}$ Faculty of Agriculture, Shizuoka University, 836 Ohya, Suruga-ku, Shizuoka 422-8529, Japan \\ ${ }^{3}$ Institute for Genetic Research and Biotechnology, Shizuoka University, \\ 836 Ohya, Suruga-ku, Shizuoka 422-8529, Japan \\ ${ }^{4}$ Graduate School of Science and Technology, Shizuoka University, \\ 836 Ohya, Suruga-ku, Shizuoka 422-8529, Japan
}

Received June 25, 2007; Accepted October 11, 2007; Online Publication, January 7, 2008

[doi:10.1271/bbb.70404]

\begin{abstract}
$\beta$-Glucosidase was partially purified from Rosa 'HohJun' petals. The enzyme was highly specific for such $\beta$ D-glucopyranosides as 2-phenylethyl $\beta$-D-glucopyranoside. The optimal activity was observed at pH 6.0 and $35^{\circ} \mathrm{C}$. The enzymes were composed with two proteins (160 and $155 \mathrm{kDa}$ ) by blue native-PAGE, and were classified in a family 1 glucosidase based on LC-MS/MS analyses.
\end{abstract}

Key words: $\beta$-glucosidase; Rosa 'Hoh-Jun'; petal; 2phenylethyl $\beta$-D-glucopyranoside; blue native-PAGE

Such flower scent compounds as 2-phenylethanol (2PE), geraniol and benzylalcohol have been reported to be present in the form of monoglycosides and/or diglycosides in plant tissues. ${ }^{1,2)}$ These glyco-conjugates of volatile compounds are hydrolysed by $\beta$-glucosidase or endoglycosidase, e.g., $\beta$-primeverosidase, to release the volatile compounds for emission from plant tissues. ${ }^{3,4)}$ In some flowers, floral scent emission is concurrent with an increase in $\beta$-glucosidase activity. ${ }^{3)} 2$ Phenylethyl $\beta$-D-glucopyranoside (2PE $\beta$-Glc) is one of the main glycoconjugates in such Damask roses as Rosa damascena Mill. and $R$. 'Hoh-Jun.' ${ }^{5)}$ In our previous study, ${ }^{6)}$ we have confirmed that 2-phenyl- $N$-glucosylacetamidiumbromide, a glycone-specific $\beta$-glucosidase inhibitor, inhibited the hydrolysis of $2 \mathrm{PE} \beta$-Glc in an enzymatic reaction by using enzymes prepared from the petals of these roses. 2-Phenyl- $N$-glucosyl-acetamidiumbromide also partially inhibited the emission of $2 \mathrm{PE}$ from rose petals. These results indicate the involvement of $\beta$-glucosidase in the emission of $2 \mathrm{PE}$ from rose flowers. To elucidate the role of $\beta$-glucosidase, we purified and characterized the enzyme from $R$. 'HohJun' petals.

The $\beta$-glucosidase activity was measured in a standard assay by the method of Yamamoto et al. ${ }^{7)}$ with some modifications. The reaction mixture $(200 \mu \mathrm{l})$ consisting of $5 \mathrm{~mm} 2 \mathrm{PE} \beta$-Glc and an enzyme solution in a $50 \mathrm{~mm}$ citrate buffer ( $\mathrm{pH}$ 6.0) was incubated for $15 \mathrm{~min}$ at $30^{\circ} \mathrm{C}$. The reaction was quenched by adding a $0.1 \mathrm{M}$ trichloroacetic acid solution $(100 \mu \mathrm{l})$. The amount of 2PE released from $2 \mathrm{PE} \beta$-Glc was analyzed by HPLC under the following conditions: column, RP-18GP Aqua $(5 \mu \mathrm{m}, 4.6 \times 150 \mathrm{~mm})$; detection, $205 \mathrm{~nm}$; column temperature, $40^{\circ} \mathrm{C}$; sample temperature, $15^{\circ} \mathrm{C}$; injection volume, $20 \mu \mathrm{l}$; mobile phase $\mathrm{A}$, a $10 \mathrm{~mm}$ phosphate buffer ( $\mathrm{pH}$ 6.0); mobile phase $\mathrm{B}$, acetonitrile; gradient condition, $35-70 \%$ of $\mathrm{B}$ over $10 \mathrm{~min}$; flow rate, $1 \mathrm{ml} /$ min. 2PE was detected at $3.3 \mathrm{~min}$. One unit of enzyme activity is defined as the amount releasing $1 \mu$ mole of 2PE per min. The glycosidic compounds of the volatile aglycones were chemically prepared according to the reported methods. ${ }^{6}$ Protein concentration was measured by using a DC protein assay kit (Bio-Rad), with bovine serum albumin as a standard.

Cell free extracts were prepared from lyophilized $R$. 'Hoh-Jun' flower petals $(0.5 \mathrm{~g}$, stages 4 to 6) with $100 \mathrm{ml}$ of buffer A $(0.1 \mathrm{M}$ potassium phosphate at $\mathrm{pH} 7.5$, containing $0.5 \%$ 3-[(3-cholamidopropyl)-dimethylamino]-1-propanesulfonate (CHAPS), $1 \mathrm{~mm}$ EDTA, 2 mM DTT, 0.5 mM PMSF, and 1\% glycerol) and $1 \mathrm{~g}$ of Polyclar 10. After centrifuging at $4000 \times g$ for

\footnotetext{
$\dagger$ To whom correspondence should be addressed. Tel/Fax: +81-54-238-4870; E-mail: acnwata@agr.shizuoka.ac.jp

Abbreviations: 2PE, 2-phenylethanol; 2PE $\beta$-Glc, 2-phenylethyl $\beta$-D-glucopyranoside; BN-PAGE; blue native-polyacrilamide gel electrophoresis; CHAPS, 3-[(3-cholamidopropyl)-dimethylamino]-1-propanesulfonate; $p \mathrm{NP}, p$-nitrophenyl
} 
$20 \mathrm{~min}$, the supernatant was brought to $20-75 \%$ saturation with solid ammonium sulfate at $4{ }^{\circ} \mathrm{C}$. The pellet was collected after centrifuging at $4000 \times g$ for $20 \mathrm{~min}$, then dissolved in buffer B (10 mM citrate at $\mathrm{pH} 5.0$, containing $0.1 \%$ CHAPS and $1 \%$ glycerol), and desalted on a PD-10 column that had been equilibrated with buffer B. The desalted solution was applied to an SP Sepharose FF column $(3 \mathrm{ml})$ that had been equilibrated with buffer B. The column was washed with $9 \mathrm{ml}$ of the same buffer, and then eluted with $9 \mathrm{ml}$ of buffer B containing $0.5 \mathrm{M} \mathrm{NaCl}$. The eluted fraction was desalted on a PD-10 column with buffer B. The desalted fraction was applied to a Mono S 4.6/100 PE column that had been equilibrated with buffer B. Proteins with $\beta$-glucosidase activity were eluted by a linear gradient of $\mathrm{NaCl}$ from $0 \mathrm{M}$ to $0.5 \mathrm{M}$ in buffer $\mathrm{B}$ at a flow rate of $1 \mathrm{ml} / \mathrm{min}$. The $\beta$-glucosidase activity was detected in a single peak at $0.4 \mathrm{M} \mathrm{NaCl}$. The $\beta$-glucosidase-active fractions were combined and concentrated, and the concentrate was dissolved in buffer $\mathrm{C}(10 \mathrm{~mm}$ potassium phosphate at $\mathrm{pH} 7.0$, containing $0.1 \%$ CHAPS and $1 \%$ glycerol) by ultrafiltration (Nanocep 30K Omega, Pall Corporation). Finally, $\beta$-glucosidase was purified 36 -fold from the cell free extract from rose petals with a specific activity of $1.1 \mathrm{U} / \mathrm{mg}$ and $13 \%$ yield. The $\beta$-glucosidase sample achieved the maximal activity at $\mathrm{pH} 6.0$ when $2 \mathrm{PE} \beta$ Glc was used as a substrate. The enzyme was most stable at pH 7.5, but slowly inactivated at below pH 5.0. The optimum temperature for the enzyme reaction was $35^{\circ} \mathrm{C}$, and inactivation occurred at temperatures above $45^{\circ} \mathrm{C}$.

Table 1 shows the substrate specificity of the partially purified enzyme toward various substrates. The enzyme showed high activity toward 2PE $\beta$-Glc, $(S)$-citronellyl

Table 1. Substrate Specificity of the Ppartially Purified Enzymes toward the Glycoconjugates of $p$-Nitorophenol and Volatile Compounds

Each substrate was used at a $5 \mathrm{~mm}$ concentration. The activity of the 2PE $\beta$-Glc sample $(1.1 \mu \mathrm{mol} / \mathrm{mg}$ of protein $/ \mathrm{h})$ is regarded as $100 \%$. The activities toward the Z-3-hexenyl and $(S)$-citronellyl glycosides were also assessed by HPLC. Each value is the mean of duplicate experiments. The enzyme activity was determined spectrophotometrically $(405 \mathrm{~nm})$ for $p$-nitrophenol when $p$-nitrophenyl $(p \mathrm{NP})$ glycosides were used as substrates.

\begin{tabular}{lc}
\hline \multicolumn{1}{c}{ Substrate } & Relative activity (\%) \\
\hline \hline$p$-nitrophenyl $\beta$-D-glucopyranoside & 58 \\
$p$-nitrophenyl $\beta$-D-galactopyranoside & 18 \\
$p$-nitrophenyl $\alpha$-D-glucopyranoside & 0 \\
$p$-nitrophenyl- $\alpha$-D-galactopyranoside & 0 \\
2-phenylethyl $\beta$-D-glucopyranoside & 100 \\
2-phenylethyl $\beta$-D-galactopyranoside & 2 \\
2-phenylethyl $\beta$-D-xylopyranoside & 0 \\
(S)-citronellyl $\beta$-D-glucopyranoside & 88 \\
(S)-citronellyl $\beta$-D-galactopyranoside & 0 \\
$(S)$-citronellyl $\beta$-D-xylopyranoside & 0 \\
Z-3-hexenyl $\beta$-D-glucopyranoside & 105 \\
Z-3-hexenyl $\beta$-D-galactopyranoside & 0 \\
$Z$-3-hexenyl $\beta$-D-xylopyranoside & 0 \\
\hline
\end{tabular}

$\beta$-D-glucopyranoside, and Z-3-hexenyl $\beta$-D-glucopyranoside, moderate activity toward $p \mathrm{NP} \beta$-D-glucopyranoside, and weak activity toward $p$ NP $\beta$-D-galactopyranoside and 2PE $\beta$-D-galactopyranoside. The enzyme showed no activity toward the other substrates. These results suggest that the partially purified enzyme was highly specific to $\beta$-glucopyranosides. In addion, the enzyme activity was inihibited by 2 -phenyl- $N$-glucosylacetamidiumbromide, a glycone-specific $\beta$-glucosidase inhibitor.

The partially purified enzyme was further separated by blue native-polyacrilamide gel electrophoresis (BNPAGE), beeing performed by the method of Schägger and Von Jagow ${ }^{8)}$ with some modifications. After electorophoresis, the gel was stained with $5 \mathrm{~mm} 4-$ methylumbelliferyl $\beta$-D-glucopyranoside ( $\mathrm{pH}$ 5.0) for $10 \mathrm{~min}$ at $30^{\circ} \mathrm{C}$. Two activity bands were detected at 160 and $155 \mathrm{kDa}$ (Fig. 1A and B, bands 1 and 2, respectively). A gel piece containg two activity bands was cut out, and the proteins were extracted with buffer A to show activities toward 2PE $\beta$-Glc and $p$ NP $\beta$-D-glucopyranoside.

To identify the protein complexes and resolve their composition, these bands were further subjected by twodimensional BN/SDS-PAGE. ${ }^{9)}$ The strip from firstdimension BN-PAGE were cut out and then applied to second-dimension SDS-PAGE. Spots 1 and 2 derived from bands 1 and 2, respectively, were detected on the SDS gel (Fig. 1C). The molecular masses of spots 1 and 2 were both approximately $54 \mathrm{kDa}$. These native proteins were thought to be trimers. Spots 1 and 2 were excised and digested with trypsin, and the resulting peptides were analyzed by LC/Linear Ion Trap-Time of Flight MS. A MASCOT database search of the MS/MS data for the several tryptic peptides derived from spots 1 and 2 indicated that some of the sequences of the peptides were identical to the theoretical tryptic peptides of the prunasin hydrolase isoform PHA precursor in Prunus serotina (AAF34650), and $\beta$-glucosidase in Hordeum vulgare (AAA87339) (Table 2). Three peptides, FGINYVDYDNGLKR, YKEDVGIMK and NMGFDAYR, were identified from both spots 1 and 2, and FSISWSR was identified from spot 1. Although details of the differences in the proteins of spots 1 and 2 were not clear, the sequence motifs detected in the amino acid sequences were those of plant members of the glycoside hydrolase family 1 , including $P$. avium $\beta$-glucosidase (AAA91166), P. serotina amygdalin hydrolase isoform AH I precursor (AAA93234), and $P$. serotina prunasin hydrolase isoform PH B precursor (AAL39079). Many of the $\beta$-glucosidases hydrolizing the glycosides of secondary metabolites in planta belong to family 1 . The $\beta$-glucosidase is therefore suggested to be classified in the family 1 glucosidase.

To clarify the mode of hydrolysis of the $\beta$-glucosidases and the relationship between the $\beta$-glucosidase and $2 \mathrm{PE}$ emission from rose flowers, cloning and characterization of these enzymes are now in progress. 

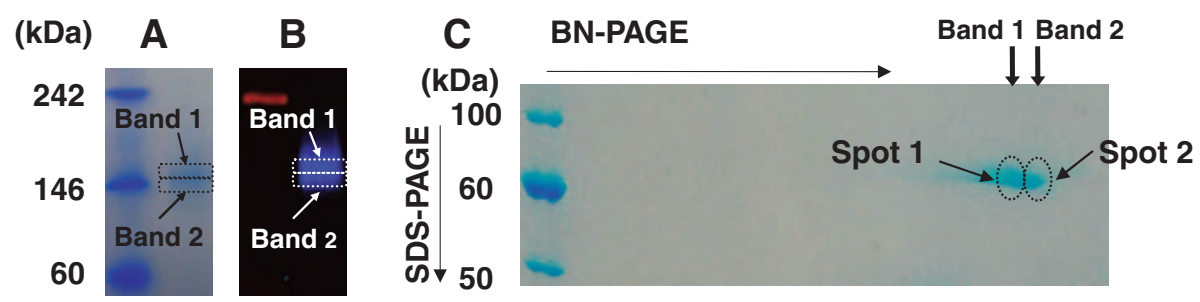

Fig. 1. Identification of the $\beta$-Glucosidases in Rose Petals by BN-PAGE and BN/SDS-PAGE.

A, BN-PAGE, Coomassie staining. B, BN-PAGE, activity staining with 4MUG. C, BN/SDS-PAGE, Coomassie staining. BN-PAGE: The sample was prepared by mixing $6.5 \mu \mathrm{l}$ of the enzyme solution, $2.5 \mu \mathrm{l}$ of native PAGE sample buffer (Invitrogen), and $1 \mu \mathrm{l}$ of $5 \% \mathrm{Coomassie}$ G250. The sample was electrophoresed on $4-16 \%$ polyacrylamide gel with $0.002 \%$ Coomassie G250 in the cathode buffer. Native gel protein standards were obtained from Invitrogen.

Table 2. Identified Peptide Fragments in Spots 1 and 2

The peptide sequences were identified by using the Mascot search engine.

\begin{tabular}{|c|c|c|c|c|}
\hline $\begin{array}{c}\text { Observed } \\
m / z\end{array}$ & Charge & Sequence & Matched protein & $\begin{array}{l}\text { Ion } \\
\text { score }\end{array}$ \\
\hline \multicolumn{5}{|l|}{ Spot 1} \\
\hline 558.6 & $3+$ & FGINYVDYDNGLKR & $\begin{array}{l}\text { Prunasin hydrolase isoform PHA precursor } \\
{[\text { Prunus serotina }]}\end{array}$ & 90 \\
\hline 541.7 & $2+$ & YKEDVGIMK & $\begin{array}{l}\text { Prunasin hydrolase isoform PHA precursor } \\
\text { [Prunus serotina }]\end{array}$ & 66 \\
\hline 495.2 & $2+$ & NMGFDAYR+Oxidation & $\beta$-Glucosidase $[$ Hordeum vulgare $]$ & 41 \\
\hline 441.7 & $2+$ & FSISWSR & $\beta$-Glucosidase [Hordeum vulgare] & 44 \\
\hline \multicolumn{5}{|l|}{ Spot 2} \\
\hline 558.6 & $3+$ & FGINYVDYDNGLKR & $\begin{array}{l}\text { Prunasin hydrolase isoform PHA precursor } \\
\text { [Prunus serotina }]\end{array}$ & 80 \\
\hline 541.7 & $2+$ & YKEFVGIMK & $\begin{array}{l}\text { Prunasin hydrolase isoform PHA precursor } \\
\text { [Prunus serotina }]\end{array}$ & 66 \\
\hline 487.2 & $2+$ & NMGFDAYR & $\beta$-Glucosidase $[$ Hordeum vulgare $]$ & 45 \\
\hline
\end{tabular}

\section{Acknowledgments}

Part of this work was supported by grant-aid to N. W. for scientific research (B)(2) from the Ministry of Education, Culture, Sports, Science, and Technology (MEXT) of Japan, and by grant-in-aid to N.W. and M.H. from Cooperation of Innovative Technology and Advanced Research in Evolutional Areas (city-area) in Central Shizuoka, MEXT of Japan.

\section{References}

1) Loughrin, J. H., Hamilton-Kemp, T. R., Burton, H. R., Andersen, R. A., and Hildebrand, D. F., Glycosidically bound volatile components of Nicotiana sylvestris and N. suaveolens flowers. Phytochemistry, 31, 1537-1540 (1992).

2) Schulz, G., and Stahl-Biskup, E., Essential oils and glycosidic bound volatiles from leaves, stems, flowers and roots of Hyssopus officinalis L. (Lamiaceae). Flavour Fragr. J., 6, 69-74 (1991).

3) Reuveni, M., Sagi, Z., Evnor, D., and Hetzroni, A., $\beta$ Glucosidase activity is involved in scent production in Narcissus flowers. Plant Sci., 147, 19-24 (1999).

4) Guo, W., Ogawa, K., Yamauchi, K., Watanabe, N., Usui, $\mathrm{T}$., Luo, S., and Sakata, K., Isolation and characterization of a $\beta$-primeverosidase concerned with alcoholic aroma formation in tea leaves. Biosci. Biotechnol. Biochem., 60, 1810-1814 (1996).

5) Watanabe, S., Hashimoto, I., Hayashi, K., Yagi, K., Asai, T., Knapp, H., Straubinger, M., Winterhalter, P., and Watanabe, N., Isolation and identification of 2-phenylethyl disaccharide glycosides and mono glycosides from rose flowers, and their potential role in scent formation. Biosci. Biotechnol. Biochem., 65, 442-445 (2001).

6) Hayashi, S., Yagi, K., Ishikawa, T., Kawasaki, M., Asai, T., Picone, J., Turnbull, C., Hiratake, J., Sakata, K., Takada, M., Ogawa, K., and Watanabe, N., Emission of 2phenylethanol from its $\beta$-D-glucopyranoside and the biogenesis of these compounds from $\left[{ }^{2} \mathrm{H}_{8}\right]$ L-phenylalanine in rose flowers. Tetrahedron, 60, 7005-7013 (2004).

7) Yamamoto, S., Okada, M., Usui, T., and Sakata, K., Isolation and characterization of a $\beta$-primeverosidase-like endo-manner $\beta$-glycosidase from Aspergillus fumigatus AP-20. Biosci. Biotechnol. Biochem., 66, 801-807 (2002).

8) Schägger, H., and von Jagow, G., Blue native electrophoresis for isolation of membrane protein complexes in enzymatically active form. Anal. Biochem., 199, 223-231 (1991).

9) Zerbetto, E., Vergani, L., and Dabbeni-Sala, F., Quantification of muscle mitochondrial oxidative phosphorylation enzymes via histochemical staining of blue native polyacrylamide gels. Electrophoresis, 18, 2059-2064 (1997). 